\title{
Chinese FDI and Economic Growth of Sub-Saharan African Countries: PIM Method and Quantile Regression in Panel Data
}

\author{
EKA Fred \\ Faculty of Economics and Applied Management, University of Douala, \\ P.O; Box:4032, Douala, Cameroon ekafred@gmail.com
}

\begin{abstract}
This article explores the impact of Chinese investment flows on the growth rate of 49 SSA countries over the period from 2003 to 2020 . The estimation strategy consists of building the capital stock using the perpetual inventory method (PIM). The quantile estimator has the advantage of being robust in the case of outliers and / or scattered errors because it penalizes deviations less. We will apply the appropriate estimation strategy (Canay, 2011) in order to neutralize the econometric problem of "incident parameters". Our results confirm a positive impact of Chinese investments on GDP per capita in SSA, which remains limited.
\end{abstract}

Keywords: Chinese FDI, GDP per capita, Sub-Saharan Africa, PIM method, Two-step estimator, Quantile Regression.

JEL Classification : O4, F21, F43

DOI: $10.7176 / \mathrm{JESD} / 12-14-02$

Publication date:July $31^{\text {st }} 2021$

\section{Introduction}

China is increasingly emancipating itself in SSA and their leaders need to maintain mutually beneficial economic relations in order to resume their development process. Overall, the Chinese presence has positively benefited the growth of African countries in recent years. However, many people question the quality of the Sino-African relationship, highlighting China's appetite for natural resources and the very little interest it seems to be given to certain aspects of the continent's long-term development. Other authors stress the possibility for African countries to make the most of their economic relations with China, by better negotiating contracts in order to defend their interests.

By the way, there seems to have been a break in Sino-African economic relations since 2012. Indeed, after a sharp increase of $10 \%$ during the early 2010s, China's GDP growth slowed (6.5\% in 2017 against $14.2 \%$ ten years earlier). Chinese leaders have established a gradual process of economic rebalancing aimed at shifting the economy towards a more sustainable model, where growth will be driven by investment, less by exports and more by domestic consumption including services.

China's lower growth rates and shifting demand are already affecting commodity prices, with far-reaching effects on global mineral markets. At the same time, the tripling of Chinese labor costs over the past decade has allowed African countries with high labor and low wages to compete with some Chinese producers. Data from the China-Africa Initiative shows that all three key indicators (Chinese investment in Africa, China-Africa trade, and Chinese loans to Africa) are on the decline. Which leads us to a major thought-provoking question. Is it the contribution of Chinese investment flows to the growth rate of SSA countries?

To answer this problem, this article is organized into seven sections: section I focuses on stylized facts and the research question. section II aims to transcribe how Chinese investments in SSA can affect the per capita growth of SSA countries. Section III presents the logic of construction of capital stocks through the PIM method. Section IV proposes the panel quantile estimator theorized by Canay (2011). Section V is devoted to the data and to the explanation of the two models to be estimated in an impact analysis logic (With - Without). Section VI presents the results of the various estimates. Finally, section VII is that of policy recommendations inspired by the results.

\section{Chinese FDI and Economic Growth in SSA.}

Busse, Erdogan and Muhlen (2016) concluded that Chinese FDI has an impressive impact on growth in Africa. Similarly, J. Weisbrod and A. Whalley (2011) who assessed the impact of Chinese FDI on 13 major African economies found that FDI contributed 0.5\% to GDP growth over the period. 1990-2008. Fu and Buckley (2015) reach a similar conclusion in which a $10 \%$ increase in the share of Chinese FDI in inward FDI in Africa, increased GDP per capita by $0.09 \%$. As the share of Chinese FDI in total inward FDI to Africa increased from $1.85 \%$ in 2004 to $6.85 \%$, its highest level in 2007 , which means a contribution of $0.045 \%$ per capita growth in Africa over the period 2004-2007.

The Chinese presence has been a factor in the growth and elevation of well-being in Africa (Chaponnière, 2012). China's economic impact on Africa has manifested itself both structurally and cyclically by causing less dependence on the sole engine of economic growth that Western countries have hitherto constituted. 
Chinese investments help support GDP growth by contributing to local capacity building, through effective technology transfer and by helping to increase the level of exports in several African countries (Besada, Wang and Whalley, 2008). In SSA countries that are rich in natural resources, Chinese investments promote economic growth (Mlachila and Takebe, 2011). The work of Lessoua A. and Diaw D. (2012) shows a positive contribution of Chinese FDI inflows on the growth of SSA countries. Some studies have shown the absence of positive effects and sometimes even the emergence of negative effects of Chinese FDI on per capita growth in SSA countries (Diaby, 2014).

Chinese FDI is generally considered to be less averse to country risks, macroeconomic instability (Sanfilippo, 2010) and following a logic of political non-interference and the absence of conditionalities. They have thus enabled SSA countries rich in raw materials, but with financial restrictions from the international community, to have access to other financing necessary to maintain their economic growth. However, Chinese FDI is also interested in SSA countries which have very little potential, but with a business climate favorable to investment (liberalization, limited competition on the national market, etc.).

Mlachila and Takebe (2011) provide evidence of Chinese FDI contributing to the rapid growth of the oil sector in South Sudan and strengthening the country's balance of payments. Other sectors that have benefited from FDI are manufacturing and services (Chakrabartin and Ghosh 2014; Pigato and Tang, 2015). China has focused on agro-industry and garment manufacturing in Ghana (Waldkirch, 2010) and has helped increase value addition in refining industries in Nigeria and copper in Zambia. It has contributed to the rehabilitation of rail lines in Angola, DRC, Zambia, Liberia and Guinea, which are necessary to facilitate intra and inter-country trade. Kpetigo (2012) showed that during the period from 2003 to 2009, the "services" sector contributed more in the value added to the GDP, compared to the "agriculture" and "industry" sector. And according to him, all these sectors of activity have direct and indirect effects (via spillover effects) on the growth of SSA countries.

\section{Construction of the capital stock: the PIM method (Perpetual Individual Method)}

Investment flows are the most reliable source of information on capital (OECD, 2001a). As the data on the capital stock is not available directly, we use the PIM method to construct the data.

The first phase of our empirical study consists in writing, for each country and each year, estimated data of the capital stock according to the PIM method which is often used to avoid the problems related to the statistical insufficiency on the stock variable. ${ }^{1}$.

$$
K_{t+1}
$$

The net capital stock at the start of period $t+1, \quad$ can be written as a function of the net capital stock at

$$
K_{t}
$$$$
I_{t}
$$

the start of the previous period $t$, the gross investment of the previous period, is gross fixed capital

$$
D_{t}
$$

formation, and is the geometric depreciation.

$$
K_{t+1}=K_{t}+I_{t}-D_{t}
$$

[A]

Assuming a geometric depreciation at a constant rate, we can rewrite the capital stock as:

$$
K_{t+1}=(1-\delta) K_{t}+I_{t}
$$

Repeatedly substituting this equation for the capital stock at the start of period t, leads to:

$$
K_{t+1}=\sum_{i=0}^{\infty}(1-\delta)^{i} I_{t-i}
$$

Thus, the capital stock at period $t+1$ is a weighted sum of the investment history. The weights result from geometric depreciation. Obviously, calculating the real capital stock in a precise way requires having a complete time series of past investments. Since the available time series of investments is incomplete, we can nevertheless

$$
K_{t+1}
$$

calculate the current capital stock precisely when the initial capital stock at the start of the investment time series, ${ }{ }_{0}$, is known:

\footnotetext{
${ }^{1}$ Read Sacerdoti, Brunschwig \& Tang (1998); Berthélemy \& Söderling (2001); Bosworth \& Collins (2003).
} 


$$
K_{t+1}=(1-\delta)^{t+1} K_{0}+\sum_{i=0}^{t}(1-\delta)^{i} I_{t-i}
$$

It is clear that the capital stock is the weighted sum of an initial capital stock and subsequent investment flows. However, the implementation of PIM requires information on (i) a time series of investment data, (ii) the existing rate of depreciation and (iii) the initial capital stock $\left({ }^{K_{0}}\right)$. Unfortunately, this initial value is generally unobserved (unknown) in the data.

\section{Implementations of the Perpetual Inventory Method}

Methodological differences exist in particular for the method for estimating the initial capital stock.

\section{A steady state approach (equilibrium)}

According to the econometric work of Nehru \& Dhareshwar (1993), there is a lack of available data on the investment and the GDP used to fix the initial capital stock. The estimate of the initial capital stock will be based on the work of Harberger (1978) which is based on the neoclassical theory of growth and the assumption that the economy is in its stable state. As a consequence of this assumption, production increases at the same rate as the capital stock. It follows from equation [B] that the growth rate can be expressed as follows :

$$
g_{G D P}=g_{k}=\frac{K_{t+1}-K_{t}}{K_{t}}=\frac{I_{t}}{K_{t}}-\delta
$$

Solving this equation for the capital stock in period t leads to:

$$
K_{t}=\frac{I_{t}}{g_{G D P}+\delta}
$$

Thus, if the economy of SSA countries is in its stable state, information on the current level of the growth

$$
I_{t}
$$

rate $(\mathrm{g})$, the depreciation rate $(\delta)$ and the investment $(\quad)$ are sufficient to calculate the initial capital stock. It should be noted that gross investment is reported by gross fixed capital formation in constant value (US dollars 2005).

The main difficulty will therefore come from the fact that the initial capital stock will depend crucially on information for a single year. A short-term shock in the first period would lead to a highly biased assessment of the initial capital stock. Aware of this problem, Harberger (1978) initially chose a three-year average instead of a single year to generate more stable and reliable capital stock estimates. Nehru and Dhareshwar (1993) propose an alternative procedure. The latter regress the time series of investments in logarithmic form and then use the adjusted value of the first period (which they do not specify in detail) to calculate the initial capital stock (R. Inklaar and P. Timmer, 2013). This method effectively leads to superior results, especially in the early years of the investment time series.

In accordance with the scientific literature on the subject, a geometric capital depreciation rate of $5 \%$ will be used. Indeed, a rate of between 4 and 5\% would be suitable for DCs, in particular those of SSA (Nehru and A. Dhareshwar [1993]).

The second phase of our methodological construction consists in excluding Chinese FDI flows from the capital stock of SSA countries. If we consider that there can be several sources of incoming FDI flows, the rewriting of [A], makes it possible to specify the calculation procedure, namely:

$$
K_{i, t, T}=\sum_{j=a}^{z} \text { finvest }_{j, i, t}+(1-\delta) K_{i, t-1}
$$

$K_{i, t, T}$

is the total capital stock, which includes all the investment flows received (net inflows), regardless of the origin of the country. $\sum_{j=a}^{z}$ finvest $_{j, i, t}$ is the flow of FDI from investor $\mathrm{j}$ to SSA countries (i) for period t. Investors are designated by the set $\{a, b, c \ldots z\}$ where each of them corresponds to a given letter; To this end,

$$
K_{i, t-1}
$$

there are as many letters as there are investors is the value of the capital stock for period $t-1$.

Chinese FDI flows are first deflated using the United States consumer price index provided by the IMF 
(World Economic Outlook, WEO).

$$
\overline{K_{i, t}}=K_{i, t}-\text { finvest }_{\text {chine,i,t }}
$$

$\overline{K_{i, t}}$ is the estimated capital stock without taking into account Chinese FDI flows. The considerable advantage of this method lies in the fact that all the data on FDI flows are necessarily linked to each other.

However, it would be wise to apply the appropriate estimation strategy in order to neutralize the econometric problem of "incident" parameters, hence the need to study the two-step quantile regression estimator on panel data (Canay, 2011).

\section{Quantile panel regressions: Two-step estimators (Canay, 2011)}

Quantile regressions are statistical methods which consist in describing the impact of explanatory variables on a variable of interest.

The quantile estimator is just as efficient (respectively more efficient) than the OLS estimator when the distribution of errors is Gaussian (respectively non-Gaussian) (Koenker and Bassett, 1978).

In quantile regression, the effect of the explanatory variables $(\mathrm{X})$ is specific according to the quantile $(\tau)$ considered:

$$
Q_{\tau}(Y_{\mid \mathrm{X})=\mathrm{X}}, \gamma_{\tau} \rightarrow^{\gamma_{\tau}=\operatorname{argmin} E} \underbrace{\min }_{\gamma} f_{\tau}\left(Y-X^{\prime} \gamma\right)_{]}
$$

In the linear regression model, the conditional expectation of the dependent variable $(\mathrm{Y})$ by the explanatory variable $(\mathrm{X})$ is modeled as follows:

$$
\left.E\left(Y_{\mid \mathrm{X}}\right)=E\left(X^{\prime} \gamma_{0}{ }_{\mathrm{X}}\right)=X^{\prime} \gamma_{0} \rightarrow \gamma_{\gamma}^{\gamma_{0}=\operatorname{argmin} E}\left(Y-X^{\prime} \gamma\right)^{2}\right]
$$

One of the advantages of quantile regression is that it penalizes large deviations less. Quantile regression solves the limits inherent in the mean. It makes it possible to have a more precise description of the whole of the distribution of a variable of interest conditional on its determinants, unlike a simple linear regression which focuses on the conditional mean.

However, when working with panel data, one should be careful about using this method. The problem of "incident parameters" can arise which comes from the fact that the number of parameters to be estimated tends to infinity when $\mathrm{n}$ becomes very large. This problem makes the properties of the estimators asymptotic. In general, the estimators are incompatible. Another problem is the computational load, because it is necessary to optimize on a very large space (Givord and D'Haultfoeuille, 2013). In fact, if the period T is fixed and if it increases (potentially less quickly than $\mathrm{n}$ ) then the number of parameters is constant per individuals. There is a deep link between the reduction of bias and the orthogonalization of the parameters to be estimated (Cox and Reid, 1987). Indeed, a nonlinear econometric approach is not suitable with the existence of fixed individual effects. Therefore, a simultaneous estimation of the structural parameters of the model, in fixed number and of the individual effects, the number of which increases with the size of the panel, leads to estimation biases attributable to the problem of "incident parameters" (Lancaster, 2000).

Canay (2011) proposes a two-step method to eliminate the fixed effects, since the fixed effects have an impact on the dependent variable in the same proportions regardless of the quantile used.

It should be noted that the basic assumptions of the quantile model assume that the effect of the covariates in the quantile regression depends on the quantile considered. According to Canay (2011), fixed effects ( ${ }^{i}$ ) are variables whose position can be changed.

Considering that the observed covariate variables $\left(X_{i, t}\right)$ and not observed $\left({ }^{v_{i, t}}\right)$ depend on the considered quantile $(\tau)$ while the fixed covariates $\left({ }^{\alpha_{i}}\right)$ are the only ones that do not depend on the quantile; the nonlinear theoretical model can be written as follows:

$$
Y_{i, t}=X_{i, t}^{\prime} \gamma(\tau)+\alpha_{i}+v_{i, t}(\tau) \quad E\left(v_{i, t}, X_{i}, \alpha_{i}\right)=0
$$

Suppose that $\left({ }^{\alpha_{i}}\right)$ or a "location shift variable" then $\left({ }^{\alpha_{i}}\right)$ can also be based on the conditional mean of $Y_{i, t}$

The first phase of the procedure of "neutralizing" the individual fixed effects amount to estimating $\gamma$ in ordinary least squares with the "within" estimator in order to recover the fixed effects 


$$
\hat{\alpha}_{i} \equiv T^{-1} \sum_{t=1}^{T}\left[Y_{i, t}-X_{i, t}^{\prime} \hat{\gamma}\right] \equiv E_{\left[Y_{i, t}-X_{i, t}^{\prime} \hat{\gamma}\right]}
$$

In the second phase, we generate a new variable to estimate ${ }^{\hat{Y}_{i, t}}$; which does not contain fixed effects.

$$
\hat{Y}_{i, t} \equiv Y_{i, t}-\alpha_{i}
$$

According to Canay (2011), the panel data two-step quantile regression estimator is defined as follows:

$$
\hat{\gamma}(\tau) \equiv \arg (\underbrace{\min }_{\gamma}\left(n T^{-1}\right) \sum_{t=1}^{T} \sum_{i=1}^{n}\left[f_{\tau}\left(\hat{Y}_{i, t}-X_{i, t}^{\prime} \gamma\right)\right]) \equiv \arg (\underbrace{\min }_{\gamma} E_{n, t}\left[f_{\tau}\left(\hat{Y}_{i, t}-X_{i, t}^{\prime} \gamma\right]\right)
$$

Intuitively, the two-step estimator of equation $(\mathrm{G})$ works because:

$$
\hat{Y}_{i, t} \rightarrow Y_{i, t}^{*} \equiv Y_{i, t}-\alpha_{i} \text { like } \mathrm{T} \rightarrow \propto \text { où } \rightarrow \text { denotes weak convergence. }
$$

This two-step approach has the advantage of being intuitive and simple, it gives convergent, consistent and asymptotically normal estimates but only when the period is very large. Koenker (2004) proposes to simultaneously estimate the set of fixed effects, using a penalization term to avoid too large a dispersion of the many terms. But his method suffers from the same limitations since the period is long. This procedure is very cumber some in standard econometric software when the number of observations is high, and raises the question of the choice of the penalty coefficient $\lambda$ (Givord and d'Haultfoeuille, 2013). This estimator just like that of Canay, only converges asymptotically with the period $\mathrm{T}$. There is a convergence between these two estimators is the fact that the fixed effects only play a role of "translation" on the distribution of interest, which poses a considerable problem.

\section{Data and estimates}

The dependent variable ${ }^{i, t}$ is the economic growth measured by the growth of the GDP per capita. ${ }_{i, t}$ is estimated in two phases: per capita growth "with" $\left(Y_{i t T}\right)$ and "without" taking into account Chinese FDI $\left(\bar{Y}_{i, t}\right)$. The two variables of interest are the capital stocks expressed in logarithm, with $\left(K_{i t T}\right)$ and without taking into account Chinese FDI flows $\left(\bar{K}_{i, t}\right)$.

Data on Chinese FDI flows to Africa are transcribed and compiled in the database MOFCOM annual statistics. The data cover 49 SSA countries, over the period 2003-2020. A set of explanatory variables (W) from the "WDI" of the World Bank, UNCTAD, IRCG, " United Nations Millennium Development Goals are mostly taken from the literature, in particular:

Per capita GDP growth, terms of trade and trade openness, human capital, money supply and public deficit, financial and political instability, agricultural productivity, health and the environment.

$$
\begin{aligned}
& \text { [1] Estimate «WITH » } q_{\tau}\left(Y_{i t T}\right)=\gamma(\tau) K_{i, t, T}+\lambda W+\varepsilon_{i t} \\
& \text { [2] Estimate «WITHOUT » } q_{\tau}\left(\bar{Y}_{i t}\right)=\gamma(\tau) \bar{K}_{i, t}+\lambda W+\varepsilon_{i t}
\end{aligned}
$$


Table 1. Definition and source of explanatory variables

\begin{tabular}{|c|c|c|}
\hline Abbreviation & Variable & Source \\
\hline GDPPC & GDP growth rate per capita & $\begin{array}{l}\text { World Economic Outlook Databases, World } \\
\text { Development Indicators }\end{array}$ \\
\hline$K_{\boldsymbol{\&}} \bar{K}$ & $\begin{array}{c}\text { Capital stock (With and Without Chinese } \\
\text { investment flow) }\end{array}$ & $\begin{array}{c}\text { Author's calculation from MOFCOM, UN } \\
\text { UNCTAD stat, OECD }\end{array}$ \\
\hline OPEN & $\begin{array}{c}\text { Trade openness (Export + Import of goods and } \\
\text { services / GDP) }\end{array}$ & World Development Indicators, World Bank \\
\hline TERM & Terms of trade & Global Economic Prospects, World Bank \\
\hline EDU & Human capital & World Development Indicators, World Bank \\
\hline AGR & Agricultural productivity & World Development Indicators, World Bank \\
\hline DEP & $\begin{array}{l}\text { Public deficit (Total general government, } \\
\text { national currency, relative to GDP) }\end{array}$ & $\begin{array}{c}\text { IMF, Africa Department and World Economic } \\
\text { Outlook databases. }\end{array}$ \\
\hline M2 & Money supply & World Development Indicators, World Bank \\
\hline COR & Political instability & International Country Risk Guide \\
\hline 2008 crisis & Financial instability (dummy variable) & Author's calculation \\
\hline $\mathrm{CO} 2$ & Environment & World Development Indicators, World Bank \\
\hline HIV & HIV mortality & Millennium Development Goals. \\
\hline
\end{tabular}

Trade

The fact that African countries do not participate intensively in trade is detrimental to economic growth (Block, 2001). The terms of trade could control the effect of external shocks (shocks on the prices of primary products, etc.) on the dynamics of growth (Hausman, Pritchett \& Rodrik, 2004). Favorable terms of trade coincide with periods of growth acceleration even if they fail to establish a meaningful causal link. After a decade of rapid development, vulnerable SSA countries face significant terms-of-trade shocks. The current volatility of commodity prices has a strong impact on growth and also leads, depending on the country, to windfall effects, unsustainable budgetary and external imbalances. The variable "trade openness" is measured by the ratio of merchandise trade to GDP, which is the sum of exports plus imports divided by GDP. It measures the importance of trade and indirectly trade restrictions. This variable comes from the World Bank.

Health

HIV undermines and undermines growth prospects by destroying future human productive potential. This destruction affects the adult population through contamination from mother to child. The mortality of the adult population would reduce economic growth (Lorentzen, McMillan and Wacziarg, 2008). The variable "HIV mortality" is introduced to control the impact of the phenomenon on economic growth. This variable includes adult and child deaths linked to HIV; it is measured as a percentage of the total population and comes from the World Bank.

Human Capital

The theory of human capital introduces the idea of education as a collective good. Indeed, Becker (1964) considers that training can be provided by the state or directly paid for by the individual, while companies have every interest in financing vocational training. This makes it possible to justify the intervention of the State in the investment in human capital in particular through free education which induces positive externalities. We will use as a proxy "education spending" as a percentage of GDP. This variable comes from the World Bank; it includes current expenditure (salaries, various salaries) and excludes physical achievements.

The Financial System

The quality of the financial system is a key element for growth. The variable "Financial development" is denoted by the money supply (M2) relative to GDP. It is the monetary aggregate larger than M1 that includes all items, such as term deposits that are less liquid. Since our article concerns SSA countries which are mostly poorly industrialized debt economies, this justifies the use of M2. In fact, in these countries most of the funding comes from donors. Financial development can improve per capita growth notably through its impact on trade, volume and quality of investments. The variable "money supply" is available in the WDI. On the other hand, there is an interconnection between the financial systems of SSA countries with other regions of the world. There could therefore be a phenomenon of contagion. Moreover, the financial crisis of 2008 is the perfect example; this crisis had a negative impact on the per capita growth of the countries. A dummy variable "Crisis of 2008" equal to 1 for the year 2008 and 0 otherwise, has been introduced in the econometric specification. This variable makes it possible to test the robustness of the contribution of Chinese FDI flows to per capita growth even during an economic crisis. A dummy variable "2008 crisis" equal to 1 for the year 2008 and 0 otherwise, was introduced in the econometric specification. This variable makes it possible to test the robustness of the contribution of Chinese FDI flows to per capita growth even during an economic crisis. A dummy variable "2008 crisis" equal to 1 for the year 2008 and 0 otherwise, was introduced in the econometric specification. This variable makes it 
possible to test the robustness of the contribution of Chinese FDI flows to per capita growth even during an economic crisis.

Public Finance

The public deficit could ultimately promote economic growth (Greiner and Semmler, 2000). According to liberal theory, an increase in the deficit would have no impact on long-term economic growth. The balance of public finances makes it possible to assess the restrictive or expansive nature of fiscal policy on condition that all public expenditure is included. The variable used is the "public deficit" compared to GDP which represents the financial balance of public administrations (group made up of the State, territorial administration etc.). This variable comes from the IMF. The deterioration of fiscal deficits is generally more marked for the group of countries rich in natural resources.

Agriculture and rural development

Since the 1990s, China has been committed to "lifting" SSA countries out of poverty, by increasing farmers' incomes and improving their living conditions. It finances the construction of farms, equipment for the local processing of agricultural products, and sends Chinese technicians responsible for transferring and popularizing techniques designed in China. The variable used here as a proxy for productivity per worker is productivity in the agricultural sector (measured in constant dollars). The variable "Agricultural productivity" is available in the WDI and integrates the output of the sector without adding intermediate inputs which can be elements of stock.

Environment

The colossal Chinese investments in SSA are the source of significant carbon emissions. Indeed, the countries which envisage a strong growth post high levels of emission of pollutants, in particular CO2. SSA countries do not have advanced technologies to improve the environmental footprint of production and consumption activities. Carbon emissions are used as a proxy for the overall intensity of activities in the economy; these activities have an impact on per capita growth. The variable "Carbon Emissions" comes from the World Bank and is taken as a logarithm. These are carbon emissions from the combustion of fossil fuels and from manufacturing activity.

\section{Political instability}

The literature broadly supports the view that corruption is bad for growth. Corruption has deleterious effects on growth (Lambsdorff, 2003). Many authors manage to establish a negative and significant link between corruption and growth (Méon and Sekkat, 2005). We measure political instability using the index from the ICRG. This variable measure "corruption" within government on a scale of 0 to 6 : the lower the score, the higher the corruption, according to the ICRG. Data shows that countries with high levels of corruption have slower growth. This finding is particularly relevant for SSA countries.

\section{The results}

The estimation results will be grouped together in the form of a summary table of all the estimation coefficients.

Our goal is to verify the existence of a significant impact differential of the capital stock on economic growth. This differential is defined according to whether or not Chinese FDI flows are considered in the

estimation of the capital stock by PIM. Furthermore, the variation between $\gamma^{*}(\tau)_{[1] \text { and }} \gamma^{*}(\tau)_{[2]}$ gives us an indication of the magnitude of the impact of the capital stock on per capita growth in SSA countries. In other

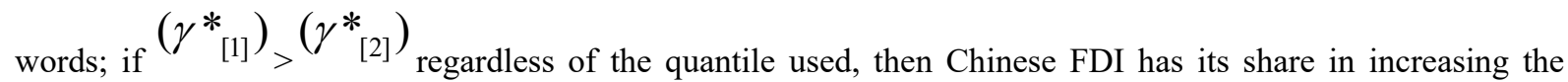
economic growth of SSA countries, linked to the accumulation of the capital stock.

The econometric approach proceeds as follows: we first started by estimating the two models using quantile regressions. According to the work of Lancaster (2000) and Koenker (2004), the variables of interest are positive but not significant in our modeling because of the problem of incident parameters. In fact, the two models are first estimated directly including each time country specificities to capture the unobserved specificity. However, the Pseudo R-squares are very good, which justifies the robustness of the choice of our explanatory variables.

Then, the two-stage quantile regression method (Canay, 2011) is then introduced after the "within" estimates of the first stage and confirms the hypothesis of a positive impact of Chinese FDI flows on per capita growth in the countries of the region. 'ASS (see appendix 1, $2 \& 3$ ). Indeed, the results show that in each of the estimates, the coefficient of model [A] is always greater than that of model [B]. Insignificant coefficients or a zero differential would mean that Chinese FDI flows have no impact on per capita growth in SSA countries; estimates show the opposite, a positive contribution from Chinese FDI.

The second point of interest will be to pay particular attention to the extent of Chinese participation: is the differential significant enough to rely on a crucial role for Chinese FDI flows in SSA? The difference (estimation coefficients) independently of the considered quantile is positive between the two models, however, it is very small according to the table below; which leads us to remain cautious about the interpretation of the results. Indeed, the results force the contribution of Chinese FDI to per capita growth to be reduced; even if there is no doubt about their positive contributions. 
Table 2. Board. Summary of differentials as a function of quantile

\begin{tabular}{|c|c|c|c|}
\hline \multirow[b]{2}{*}{ Quantile } & $\begin{array}{l}\text { Significant "WITH" coefficient (quantile } \\
\text { estimates [A] in } 2 \text { steps on panel); }\end{array}$ & $\begin{array}{c}\text { Significant coefficient "WITHOUT" } \\
\text { (quantile estimates [B] in } 2 \text { steps on } \\
\text { panel); }\end{array}$ & \multirow{2}{*}{$\begin{array}{l}\text { Differe } \\
\text { ntial in } \\
\text { absolut } \\
\text { e value }\end{array}$} \\
\hline & $\frac{\text { Variable of interest: Total capital stock }}{\text { (WITH Chinese FDI flow) }}$ & $\begin{array}{l}\text { Variable of interest: Capital stock } \\
\text { (WITHOUT Chinese FDI flow) }\end{array}$ & \\
\hline \multirow{3}{*}{$\begin{array}{c}q=0.25 \\
q=0.5 \\
q=0.75\end{array}$} & $0.0700 * * *$ & $0.069 * * *$ & \multirow{3}{*}{$\begin{array}{l}0.0001 \\
0.0002 \\
0.0003 \\
\end{array}$} \\
\hline & $0.0803 * * *$ & $0.0801 * * *$ & \\
\hline & $0.0787 * * *$ & $0.0784 * * *$ & \\
\hline
\end{tabular}

\section{Outlook and Recommandations}

Our results show a positive difference (coefficients of interest) between the estimates [1] and [2] despite the fact that there is a lack of data on Chinese FDI to SSA. This would mean that the difference could be greater if the statistical data were better exploited.

African leaders use the sums invested by China for the benefit of their country, all the more so since it is absolutely not the first foreign investor in Africa. Is it possible to reconcile the fact that, on the one hand, China appears to be Africa's leading developer in terms of infrastructure (ICA, 2016) and, on the other hand, that Western countries are essentially concentrating their efforts on development in the social sectors in order to improve the lives of populations?

We must be able to define priority investment sectors and harmonize corporate taxation to avoid the phenomenon of "tax competition" with other SSA countries. Contractual clauses between SSA countries and Chinese firms should be negotiated more rigorously in the primary sectors (mining, hydrocarbons, minerals, etc.) to avoid disproportionate advantages when signing contracts so that the local employment is valued, as well as respect for social policies.

Specialization would be very beneficial to SSA countries in the short term. However, it would be wise to use the budgetary allocation of traditional partners to carry out structural reforms in order to facilitate the establishment of investors and derive maximum benefit from them. Hence the interest of SEZs which are very effective in attracting Chinese investors by improving job creation, innovation and growth. As such, multilateral banks can join forces with Chinese financing for the construction of infrastructure in Africa. Reforms must be made at the economic, financial and political level to improve the institutional environment and competition with regard to Chinese investors in the SEZs (liberalization, tax facilities, respect for private property and reduction of the risk of expropriation, etc.), local workers (promotion of the workforce, respect and strengthening of labor law and salary reassessment, etc.) and finally to African leaders (Schiere, 2010). SSA countries must be able to combine and boost Chinese FDI and financial aid from international donors.

\section{Conclusion}

We have econometrically verified by panel data, the effect of Chinese FDI on the growth rate of 49 SSA countries over the period from 2003 to 2018. The two-step quantile regression estimator on panel data (Canay, 2011) shows that Chinese FDI has a positive but very weak effect on the economic growth rate of SSA countries. This result is not surprising because it is present in the literature (Kpetigo, 2012). Without a strong industry, African growth will remain poor in terms of formal job creation. All the more so as Chinese firms are very oriented in SSA towards the sectors of extraction of raw materials (oil, mining, timber, etc.), but also in the gas sectors (Asche and Schüller, 2008).

Nevertheless, these results should be put into perspective because of the weakness of Chinese FDI in relation to overall investment. This situation can be explained for several reasons. First, the data on Chinese FDI destined for SSA are limited and little used, in the case of countries such as Guinea Bissau, CAR, Sao Tome and Principe, Somalia and Swaziland. Then, the fact that Chinese FDI statistics do not always take into account several private sector SMEs that are setting up in Africa. Indeed, the large Chinese firms under the supervision of the central power are building several transport and telecommunications infrastructures in Africa, while Chinese SMEs are very dynamic in other sectors (textiles, durable consumer goods, electronics, etc.) d 'after Schiere and $\mathrm{Gu}$ (2011) but often ignored by official sources (MOFCOM, etc.)

To reap the benefits of Chinese FDI, leaders of SSA countries need to improve conditions for investment and build the human and institutional capacities needed to harness them. First, policies aimed at attracting Chinese FDI must be oriented towards the productive sectors of the economy, in particular the manufacturing sector. Then, to improve the well-being of the populations, it is necessary to encourage the operators of agricultural products (oleaginous fruits, sesame seeds, fresh fruits and vegetables, meat and fish), fishing, education, health and the development of infrastructure. Finally, to better redistribute wealth, poverty must be reduced and human development improved. 
Considerable regulatory efforts must be made. It would be wise for African decision-makers to continue extensive trade liberalization through the reduction of tariff barriers (trade preferences offered to African countries), in order to attract Chinese FDI which could serve SSA countries as an export platform to other countries or regions of the world.

\section{BIBLIOGRAPHY}

ARTADI E, X. SALA-I-MARTIN. (2003), "The Economic Tragedy of the 20th Century: Growth in Africa," National Bureau of Economic Research Working Paper 9865.

ASCHE H, SCHULLER, M. (2008), China's Engagement in Africa - Opportunities and Risk for Development. GTZ, Africa Department, Economic Affairs. Eschborn: Deutsche Gesellschaft fur Technische Zusammenarbeit (GTZ).

BALDACCI E., CLEMENTS B, GUPTA S. (2003), Using Fiscal Policy to Spur Growth. Finance \& Development, IMF, 40 (4).

BARRO R, X. SALA-I-MARTIN. (1997), "Technological Diffusion, Convergence and Economic Growth", Journal of Economic Growth, $\mathrm{n}^{\circ} 2$ (1), pp. 1-26.

BERLEMANN M, WESSELHOFT JE (2014), "Estimating Aggregate Capital Stocks Using the Perpetual Inventory Method "- New Empirical Evidence for 103 Countries - Review of Economics, flight. 65, issue 1, pages 1-34.

BERTHELEMY J.-C, SODERLING L. (2001), "The Role of Capital Accumulation, Adjustment and Structural Change for Economic Take off: Empirical Evidence from African Growth Episodes". World Development, 29 (2), 323-343.

BESADA H., WANG, Y, WHALLEY, J. (2008), China's Growing Economic Activity in Africa. NBER Working Paper (14024).

BLOCK, SA (2001), Does Africa Grow Differently? Journal of Development Economics, 65, 443-467.

BLOOM D, SACHS J. (1998), "Geography, Demography and Economic Growth in Africa”, Brookings Papers on Economic Activity, $\mathrm{n}^{\circ} 2$.

BLOMSTROM, M. (1986), 'Foreign Investment and Productive Efficiency: The Case of Mexico', Journal of Industrial Economics, Vol. 35, No. 1, pp. 97-110.

BOSWORTH, B., COLLINS S. (2003), The Empirics of Growth: An Update. Brookings Papers on Economic Activity (2), 113-179.

BRAUTIGAM D, XIAOYANG T. (2011), African Shenzhen: China's Special Economic Zones in Africa. Journal of Modern African Studies, 49 (1), 27-54.

BRAUTIGAM D, FAROLE, T, XIAOYANG T. (2010), China's Investment in African Special Economic Zones: Prospects, Challenges, and Opportunities. March, Economic Premise (05).

BUSSE, M., ERDOGAN, MUHLEN H. (2016), China's impact on Africa - The role of trade, FDI and aid. KYKLOS 69 (2): 228-262.

CANAY IA (2011), “A Simple Approach to Quantile Regression for Panel Data”. Econometrics Journal, 14, 368386.

CARKOVIC M, LEVINE R. (2005), “Does Foreign Direct Investment Accelerate Economic Growth?”, in M. Blomström, E.Graham and T. Moran (eds.), Does Foreign Direct Investment Promote Development ?, Institute for International Economics, Washington, DC, pp. 195-220.

CHAPONNIERE JR (2014), "The Chinese footprint in Africa", financial economics review, ${ }^{\circ} 116$, December.

CHARNOZ P, COUDIN, GAINI M. (2011), Wage inequalities in France 1976-2004: a quantile regression analysis, Technical report.

VSHO, YOONYOUNG, TIEN N. (2014), Sub-Saharan Africa's recent growth spurt: An analysis of the sources of growth, World Bank, policy research working paper, No. 6862.

COLliER P, O'CONNELL S. (2008), "Opportunities and Choices", in B. Ndulu S. O'Connel, R. Bates, P. Collier and C. Soludo (eds), The Political Economy of Economic Growth in Africa 1960-2000, Cambridge University Press.

CORNEC M. (2010), constructing a conditional gdp fan chart with an application to French business survey data mimeo Insee.

COX DR, REID N. (1987), Journal of the Royal Statistical Society. Series B (Methodological), Vol. 49, No. 1, 1-39.

DZIFA K. (2012), Participation of Chinese FDI in economic growth in Sub-Saharan Africa: Approach by the PIM method and two-step quantile regressions on panel within the framework of the annual conference for the African Development Bank.

EASTERLY W, LEVINE R. (1997), “Africa's Growth Tragedy: Policies and Ethnic Divisions”, The Quarterly Journal of Economics, $\mathrm{n}^{\circ} 112$ (4), pp. 1203-1250.

EKA F. (2018), China's contribution to the economic development of sub-Saharan African countries: Attractiveness of Central African countries and determinants of location choices. A doctoral thesis, final 
version published on October 19, CATT, University of Pau and the Adour countries, pages 63-79.

FOSU A. (2011), "Growth, Inequality, and Poverty Reduction in Developing Countries: Recent Global Evidence”, Working Paper Series UNU-WIDER, World Institute for Development Economic Research.

FU X, BUCKLEY. F. (2015), "Multi-dimensional complementarities and the growth impact of direct investment from China on host developing countries." Working Paper No. TMD-WP-69. Technology and Management Center for Development, University of Oxford.

GALVAO AF (2008), Quantile Regression for Dynamic Panel Data with Fixed Effects. Working Paper, University of Illinois, Urbana-Champaign.

GIVORD P, D'HAULTFOEUILLE (2013), Quantile regression in practice, working document, p16-18.

HARBERGER AC (1978), "Perspectives on Capital and Technology in Less Developed Countries". In: MJ Artis and AR Nobay (Eds.): Contemporary Economic Analysis, London, 42-72.

HAUSMANN, R., Pritchett, L., RODRIK D. (2004), Growth Accelerations. Faculty Research Working Papers Series, Harvard University, John F. Kennedy School of Government, RWP 04-030.

ICA (2011), Annual Report 2010: Financial Commitments and Disbursements for Infrastructure in Africa for 2010. Tunis: The Infrastructure Consortium for Africa.

JERVEN M. (2011b), "Random Growth in Africa? Lessons from an Evaluation of the Growth Evidence on Botswana, Kenya, Tanzania and Zambia, 1965-1995 ”, Journal of Development Studies, n ${ }^{\circ} 46$ (2), pp. 274294.

JERVEN M. (2009), “The Relativity of Poverty and Income: How Reliable are African Economic Statistics?" African Affairs, ${ }^{\circ}$ 109/434, pp. 77-96.

KALEMLI-OZCAN, TURAN S. (2011), HIV and Fertility Revisited. Journal of Development Economics, 96 (1), 61-65.

KHAN M. S, SENHADJI AS (2003), "Financial Development and Economic Growth: A Review and New Evidence". Journal of African Economies, 12 (2), 89-110.

KOENKER R. (2004), "Quantile regression for longitudinal data”, Journal of Multivariate Analysis 91 (1), 74-89.

KOENKER R, HALLOCK KF (2001), “Quantile regression”, Journal of Economic Perspectives 15 (4), $143-156$.

KOENKER R, BASSETT GJ (1978), “Quantile regression”, Econometrica, 46 (1), 33-50.

LAMBSDORFF JG (2003), How corruption affects persistent capital flows. Economics of Governance 4: 229243.

LANCASTER T. (2000), “The Incidental Parameter Problem since 1948”. Journal of Econometrics, 95, 391-413.

LESSOUA A, DIAW D. (2012), "Orientation trade and growth in CEMAC countries: The opportunities offered by China ", ESCE, Les cahiers de la recherche, $\mathrm{n}^{\circ} 15$, May, pp. 63-90.

LEVINE, LOAYZA R, BECK T. (2000), Financial Intermediation and Growth: Causality and Causes. Journal of Monetary Economics, 46 (1), 31-77.

LORENTZEN P, MCMILAN J, WACZIARG R. (2008), "Death and Development". Journal of Economic Growth, 13 (2), 81-124.

LUCAS RJ (1988), On the Mechanics of Economic Development. Journal of Monetary Economics, 22, 3-42. Mac Kinnon, RJ (1973). Money and Capital in Economic Development. Washington: The Brooking Institution

MC MILAN S, HARTGEN K. (2014),“What is driving the 'African growth miracle'? », NBER,working paper, $\mathrm{n}^{\circ} 20077$, April.

MADIES T, DETHIER J.-J. (2010), Fiscal Competition in Developing Countries: A Survey of the Theoretical and Empirical Literature. World Bank's Policy Research Working Paper (5311).

MANKIW, ROMER D, Weil DN (1992), "” A Contribution to the Empirics of Economic Growth". The Quarterly Journal of Economics, 107 (2), 407-437.

MATSUYAMA K. (1992), "Agricultural Productivity, Comparative Advantage and Economic Growth". Journal of Economic Theory, 58, 317-334.

MAYER J, WOOD A. (2001 b), "Africa's Export Structure in Comparative Perspective", Cambridge Journal of Economics, $\mathrm{n}^{\circ} 25$ (3), pp. 369-394.

MEON P, SEKKAT (2005), K. Does corruption grease or sand the wheels of growth? Public Choice 122, 6997.https://doi.org/10.1007/s11127-005-3988-0

MINEA A, VILLIEU P. (2010), "Endogenous Growth, Government Debt and Budgetary Regimes: A Corrigendum". Journal of Macroeconomics, 32 (2), 709-711.

MLACHILA M, Takebe M. (2011), FDI from BRICs to LICs: Emerging Growth Driver? IMF Working Paper $(11 / 178)$

NEHRU V, ASHOK D. (1993), “A New Database on Physical Capital Stock: Sources, Methodology and Results". Revista De Analisis Economico, 8 (1), 37-59.

OECD (2001), Measuring Capital: Measurement of Capital Stock, Consumption of Fixed Capital and Capital Services. Organization for Economic Cooperation and Development, Statistics. Paris: 
PAIRAULT T. (2017), "China in Africa: the weight of unbalanced economic relations", working document, 6th Asia Congress, June 26-28, pp. 1-16.

PIGATO, MIRIA, TANG, WENXIA. (2015), China and Africa: Expanding Economic Ties in an Evolving Global Context. World Bank, Washington, DC.https://openknowledge.worldbank.org/handle/10986/21788

PONOMAREVA M. (2010), Quantile Regression for Panel Data Models with Fixed Effects and Small T: Identificcation and Estimation. Working Paper, Northwestern Economics Department.

SACERDOTI E, BRUNCHWIG S, TANG J. (1998), The Impact of Human Capital Growth: Evidence from West Africa. Working Paper 98/162.

SACHS J, WARNER M. (1995), "Natural Resources Abundance and Economic Growth”, Harvard Institute for International Development.

SANFILIPPO M. (2010), Chinese FDI to Africa: what is the Nexus with Foreign Economic Cooperation? African Development Review, 22 (S1), 599-614.

SCHIERE R. (2010), Building Complementarities in Africa between Different Development Cooperation Modalities of Traditional Development Partners and China ". African Development Review, 22 (S1), 615-628.

SCHIERE R, Gu, J. (2011), Post-Crisis Prospects for China-Africa Relations. African Development Bank Group's Working Paper (124).

Whalley J, WEISBROD A. (2012), "The Contribution of Chinese FDI to Africa's Pre Crisis Growth Surge,"Global Economy Journal, De Gruyter, vol. 12 (4), pages 1-28, December.

\section{APPENDIX}

1. Direct quantile regressions in two steps on panel data (quantile 0.25 ).

[1]

EF
[2]

EF $Q R$

\begin{tabular}{|c|c|c|c|c|}
\hline \multirow[t]{2}{*}{ Capital Stock } & $-0.0692 * *$ & $0.0700 \star \star \star$ & $-0.0691 * *$ & $0.0699 \star \star \star$ \\
\hline & $(-3.31)$ & $(9.76)$ & $(-3.33)$ & $(12.22)$ \\
\hline \multirow[t]{2}{*}{ OUV } & 0.00157 & -0.000619 & 0.00162 & -0.000671 \\
\hline & $(1.39)$ & $(-0.55)$ & $(1.44)$ & $(-0.63)$ \\
\hline \multirow[t]{2}{*}{ TERM } & -0.000273 & 0.000665 & -0.000299 & 0.000692 \\
\hline & $(-0.92)$ & $(0.95)$ & $(-1.01)$ & $(1.27)$ \\
\hline \multirow[t]{2}{*}{ M2 } & -0.000957 & -0.00169 & -0.000993 & -0.00165 \\
\hline & $(-0.58)$ & $(-0.82)$ & $(-0.60)$ & $(-0.76)$ \\
\hline \multirow[t]{2}{*}{ Crise 2008} & -0.00193 & 0.0132 & -0.00288 & 0.0142 \\
\hline & $(-0.15)$ & $(0.37)$ & $(-0.23)$ & $(0.54)$ \\
\hline \multirow[t]{2}{*}{$\mathrm{DEP}$} & -0.00421 & 0.00306 & -0.00424 & 0.00309 \\
\hline & $(-1 \cdot 76)$ & $(0.97)$ & $(-1 \cdot 78)$ & (1.11) \\
\hline \multirow[t]{2}{*}{ EDU } & -0.00859 & 0.00981 & -0.00869 & 0.00992 \\
\hline & $(-1.05)$ & $(0.62)$ & $(-1.07)$ & $(0.66)$ \\
\hline \multirow[t]{2}{*}{ AGR } & $-2.26 e-11$ & $3.57 e-11$ & $-2.20 e-11$ & $3.52 e-11$ \\
\hline & $(-0.99)$ & $(1.48)$ & $(-0.97)$ & $(1.66)$ \\
\hline \multirow[t]{2}{*}{ COR } & -0.00120 & -0.0184 & -0.00102 & -0.0186 \\
\hline & $(-0.17)$ & $(-1.21)$ & $(-0.15)$ & $(-1 \cdot 38)$ \\
\hline \multirow[t]{2}{*}{$\mathrm{CO} 2$} & 0.00822 & 0.0189 & 0.00744 & 0.0197 \\
\hline & $(0.15)$ & $(0.38)$ & $(0.14)$ & $(0.44)$ \\
\hline \multirow[t]{2}{*}{ VIH } & $-0.0307 *$ & $0.0362 * * *$ & $-0.0307 *$ & $0.0362 * * *$ \\
\hline & $(-2 \cdot 44)$ & $(9.49)$ & $(-2.45)$ & $(8.53)$ \\
\hline \multirow[t]{2}{*}{ Constante } & $1.734 * *$ & $-1.862 * * *$ & $1.742 * *$ & $-1.870 * * *$ \\
\hline & $(3.68)$ & $(-7 \cdot 60)$ & $(3.69)$ & $(-8.57)$ \\
\hline Observations & 39 & 39 & 39 & 39 \\
\hline
\end{tabular}

Statistics $\mathrm{t}$ in parentheses: $* \mathrm{p}<0.05, * * \mathrm{p}<0.01, * * * \mathrm{p}<0.001$

Reading :

[1] Integrates the entire capital stock (PIM method): "WITH" regressions.

[2] Exclusion of Chinese FDI flows in the estimation of the capital stock: "WITHOUT" regressions. 
2. Direct quantile regressions in two steps on panel data (quantile 0.50)

[1]
[2]

\begin{tabular}{|c|c|c|c|c|}
\hline & $\mathrm{EF}$ & $\mathrm{QR}$ & $\mathrm{EF}$ & $Q R$ \\
\hline \multirow[t]{2}{*}{ Capital Stock } & $-0.0692 * *$ & $0.0803 \star \star \star$ & $-0.0691 * *$ & $0.0801 \star \star \star$ \\
\hline & $(-3.31)$ & $(12.39)$ & $(-3.33)$ & $(10.23)$ \\
\hline \multirow[t]{2}{*}{ OUV } & 0.00157 & -0.000235 & 0.00162 & -0.000286 \\
\hline & $(1.39)$ & $(-0.22)$ & $(1.44)$ & $(-0.28)$ \\
\hline \multirow[t]{2}{*}{ TERM } & -0.000273 & -0.00000603 & -0.000299 & 0.0000250 \\
\hline & $(-0.92)$ & $(-0.01)$ & $(-1.01)$ & $(0.04)$ \\
\hline \multirow[t]{2}{*}{$\mathrm{M} 2$} & -0.000957 & 0.000852 & -0.000993 & 0.000857 \\
\hline & $(-0.58)$ & $(0.49)$ & $(-0.60)$ & $(0.51)$ \\
\hline \multirow[t]{2}{*}{ Crise2008 } & -0.00193 & -0.0109 & -0.00288 & -0.00952 \\
\hline & $(-0.15)$ & $(-0.43)$ & $(-0.23)$ & $(-0.37)$ \\
\hline \multirow[t]{2}{*}{ DEP } & -0.00421 & 0.00115 & -0.00424 & 0.00122 \\
\hline & $(-1.76)$ & $(0.37)$ & $(-1 \cdot 78)$ & $(0.47)$ \\
\hline \multirow[t]{2}{*}{ EDU } & -0.00859 & -0.0190 & -0.00869 & -0.0188 \\
\hline & $(-1.05)$ & $(-1.22)$ & $(-1.07)$ & $(-1.17)$ \\
\hline \multirow[t]{2}{*}{$\mathrm{AGR}$} & $-2.26 \mathrm{e}-11$ & $1.02 e-12$ & $-2.20 e-11$ & $7.68 \mathrm{e}-13$ \\
\hline & $(-0.99)$ & $(0.05)$ & $(-0.97)$ & $(0.04)$ \\
\hline \multirow[t]{2}{*}{ COR } & -0.00120 & -0.00834 & -0.00102 & -0.00839 \\
\hline & $(-0.17)$ & $(-0.59)$ & $(-0.15)$ & $(-0.54)$ \\
\hline \multirow[t]{2}{*}{$\mathrm{CO} 2$} & 0.00822 & 0.0730 & 0.00744 & 0.0740 \\
\hline & $(0.15)$ & $(1.47)$ & $(0.14)$ & $(1.46)$ \\
\hline \multirow[t]{2}{*}{ VIH } & $-0.0307 *$ & $0.0318 * * *$ & $-0.0307 *$ & $0.0318 * * *$ \\
\hline & $(-2.44)$ & $(9.18)$ & $(-2.45)$ & $(8.85)$ \\
\hline \multirow[t]{2}{*}{ Constante } & $1.734 * *$ & $-1.902 * * *$ & $1.742 * *$ & $-1 \cdot 911 * * *$ \\
\hline & $(3.68)$ & $(-8.98)$ & $(3.69)$ & $(-8.88)$ \\
\hline Observations & 39 & 39 & 39 & 39 \\
\hline
\end{tabular}

Statistics $\mathrm{t}$ in parentheses: $* \mathrm{p}<0.05, * * \mathrm{p}<0.01, * * * \mathrm{p}<0.001$

Reading :

[1] Integrates the entire capital stock (PIM method): "WITH" regressions.

[2] Exclusion of Chinese FDI flows in the estimation of the capital stock: "WITHOUT" regressions. 
3. Direct quantile regressions in two steps on panel data (quantile 0.75).

[1]

[2]

\begin{tabular}{|c|c|c|c|c|}
\hline & $\mathrm{EF}$ & $Q R$ & $\mathrm{EF}$ & $Q R$ \\
\hline Capital Stock & $\begin{array}{l}-0.0692 * * \\
(-3.31)\end{array}$ & $\begin{array}{c}0.0787 \star \star \star \\
(11.18)\end{array}$ & $\begin{array}{l}-0.0691 * * \\
(-3.33)\end{array}$ & $\begin{array}{l}0.0784 \star \star \star \\
(10.61)\end{array}$ \\
\hline OUV & $\begin{array}{l}0.00157 \\
(1.39)\end{array}$ & $\begin{array}{c}-0.000436 \\
(-0.33)\end{array}$ & $\begin{array}{c}0.00162 \\
(1.44)\end{array}$ & $\begin{array}{c}-0.000459 \\
(-0.39)\end{array}$ \\
\hline TERM & $\begin{array}{c}-0.000273 \\
(-0.92)\end{array}$ & $\begin{array}{c}-0.000272 \\
(-0.48)\end{array}$ & $\begin{array}{c}-0.000299 \\
(-1.01)\end{array}$ & $\begin{array}{l}-0.000267 \\
(-0.41)\end{array}$ \\
\hline M2 & $\begin{array}{c}-0.000957 \\
(-0.58)\end{array}$ & $\begin{array}{c}0.000457 \\
(0.27)\end{array}$ & $\begin{array}{c}-0.000993 \\
(-0.60)\end{array}$ & $\begin{array}{l}0.000423 \\
(0.28)\end{array}$ \\
\hline Crise 2008 & $\begin{array}{l}-0.00193 \\
(-0.15)\end{array}$ & $\begin{array}{l}-0.0154 \\
(-0.53)\end{array}$ & $\begin{array}{l}-0.00288 \\
(-0.23)\end{array}$ & $\begin{array}{l}-0.0144 \\
(-0.33)\end{array}$ \\
\hline DEP & $\begin{array}{c}-0.00421 \\
(-1.76)\end{array}$ & $\begin{array}{c}-0.0000174 \\
(-0.01)\end{array}$ & $\begin{array}{l}-0.00424 \\
(-1.78)\end{array}$ & $\begin{array}{c}-0.0000104 \\
(-0.00)\end{array}$ \\
\hline EDU & $\begin{array}{c}-0.00859 \\
(-1.05)\end{array}$ & $\begin{array}{l}-0.0176 \\
(-1.19)\end{array}$ & $\begin{array}{l}-0.00869 \\
(-1.07)\end{array}$ & $\begin{array}{l}-0.0176 \\
(-1.32)\end{array}$ \\
\hline $\mathrm{AGR}$ & $\begin{array}{c}-2.26 \mathrm{e}-11 \\
(-0.99)\end{array}$ & $\begin{array}{c}8.60 \mathrm{e}-12 \\
(0.47)\end{array}$ & $\begin{array}{c}-2.20 \mathrm{e}-11 \\
(-0.97)\end{array}$ & $\begin{array}{c}8.72 \mathrm{e}-12 \\
(0.51)\end{array}$ \\
\hline $\mathrm{COR}$ & $\begin{array}{c}-0.00120 \\
(-0.17)\end{array}$ & $\begin{array}{c}0.000827 \\
(0.05)\end{array}$ & $\begin{array}{l}-0.00102 \\
(-0.15)\end{array}$ & $\begin{array}{c}0.000714 \\
(0.04)\end{array}$ \\
\hline $\mathrm{CO} 2$ & $\begin{array}{c}0.00822 \\
(0.15)\end{array}$ & $\begin{array}{l}0.0664 \\
(1.36)\end{array}$ & $\begin{array}{l}0.00744 \\
(0.14)\end{array}$ & $\begin{array}{l}0.0666 \\
(1.19)\end{array}$ \\
\hline VIH & $\begin{array}{l}-0.0307 * \\
(-2.44)\end{array}$ & $\begin{array}{l}0.0328 * * * \\
(7.28)\end{array}$ & $\begin{array}{l}-0.0307 * \\
(-2.45)\end{array}$ & $\begin{array}{l}0.0329 * * * \\
(8.82)\end{array}$ \\
\hline Constante & $\begin{array}{l}1.734 * * \\
(3.68)\end{array}$ & $\begin{array}{l}-1.855 * * * \\
(-7.94)\end{array}$ & $\begin{array}{l}1.742^{\star *} \\
(3.69)\end{array}$ & $\begin{array}{c}-1.859 * * * \\
(-6.55)\end{array}$ \\
\hline Observations & 39 & 39 & 39 & 39 \\
\hline
\end{tabular}

Statistics $\mathrm{t}$ in parentheses: $* \mathrm{p}<0.05, * * \mathrm{p}<0.01, * * * \mathrm{p}<0.001$

Reading :

[1] Integrates the entire capital stock (PIM method): "WITH" regressions.

[2] Exclusion of Chinese FDI flows in the estimation of the capital stock: "WITHOUT" regressions. 